\title{
INVESTIGATION OF THE LEVEL OF DNA DOUBLE-STRAND BREAKS AND MECHANISMS OF CELL DEATH UNDER IRRADIATION OF LUNG CANCER AND MELANOMA CELLS WITH ULTRA-HIGH DOSE RATE PHOTON RADIATION
}

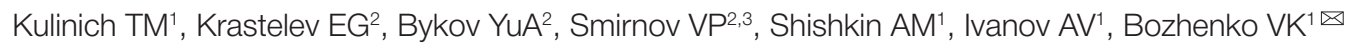 \\ ${ }^{1}$ Russian Research Center of Roentgenradiology of the Ministry of Healthcare of the Russian Federation, Moscow \\ 2 Joint Institute for High Temperatures of the Russian Academy of Sciences, Moscow \\ ${ }^{3}$ Research Institute of Technical Physics and Automation of Rosatom, Moscow
}

\begin{abstract}
Research into the effects of radiation delivered at ultrahigh dose rates $>1 \times 10^{7} \mathrm{~Gy} / \mathrm{min}$ to biological objects is a new promising area of radiobiology. The unique characteristics of the high-current nanosecond electron accelerator Mir-M enable its use in medical and biological research, specifically in the experiments aimed at investigating the effect of therapeutic doses at a dose rate up to $100 \mathrm{MGy} / \mathrm{s}$. In this work we study the effects of ultrahigh dose rate photon radiation on human lung carcinoma (A549) and melanoma (MelMtp-x) cells lines and compare them with those of the therapeutic gamma unit Rokus-AM. We show that ultrahigh dose rates induce more significant damage in the studied cell lines at doses between 2 and 7 Gy, radioresistant melanoma being more sensitive to photon radiation delivered at ultrahigh dose rates.
\end{abstract}

Keywords: photon radiation, gamma radiation, X-rays, ultrahigh dose rate, apoptosis, DNA double strand breaks

Funding: this work was supported by the Russian Science Foundation (Project 15-10355).

$\triangle$ Correspondence should be addressed: Vladimir K. Bojenko

Profsoyuznaya 86, Moscow, 117997; vbojenko@mail.ru

Received: 15.08.2018 Accepted: 28.11.2018

DOI: 10.24075/brsmu.2018.066

\section{ИССЛЕДОВАНИЕ УРОВНЯ ДВУНИТЕВЫХ РАЗРЫВОВ ДНК И МЕХАНИЗМОВ КЛЕТОЧНОЙ ГИБЕЛИ ПРИ ВОЗДЕЙСТВИИ НА КЛЕТКИ РАКА ЛЕГКОГО И МЕЛАНОМЫ ФОТОННОГО ИЗЛУЧЕНИЯ СВЕРХВЫСОКОЙ МОЩНОСТИ}

\author{
Т. М. Кулинич ${ }^{1}$, Е. Г. Крастелев ${ }^{2}$, Ю. А. Быков², В. П. Смирнов ${ }^{2,3}$, А. М. Шишкин ${ }^{1}$, А. В. Иванов ${ }^{1}$, В. К. Боженко ${ }^{\circledR}$ \\ Российский научный центр рентгенорадиологии, Москва \\ 2 Объединенный институт высоких температур Российской академии наук, Москва \\ ${ }^{3} \mathrm{AO}$ «Научно-исследовательский институт технической физики и автоматизации» Госкорпорации «Росатом», Москва
}

\begin{abstract}
Изучение влияния фотонного излучения сверхвысокой мощности (мощность дозы > 1 × 107 Гр/мин) на биологические объекты является новым и перспективным направлением радиобоиологии. Экспериментальная установка «МИР-М» обладает уникальными характеристиками, позволяющими проводить на ней медико-биологические эксперименты и изучать влияние терапевтических доз при интенсивности дозы до 100 МГр/с. Целью работы было исследовать влияние фотонного излучения сверхвысокой мощности на клетки опухолевых линий рака легкого (А549) и меланомы (MelMtp-x), провести сравнение полученных эффектов с воздействием на клетки излучения терапевтической гаммаустановки «Рокус-АМ». Показано, что излучение сверхвысокой мощности имеет большее повреждающее воздействие на клетки исследуемых опухолевых линий в диапазоне доз от 2 до 7 Гр, при этом радиорезистентная линия меланомы более чувствительна к фотонному излучению сверхвысокой мощности.
\end{abstract}

Ключевые слова: фотонное излучение, гамма-излучение, рентгеновское излучение, сверхвысокая мощность дозы, апоптоз, двунитевые разрывы ДНК

Финансирование: работа выполнена при поддержке гранта Российского научного фонда 15-10355.

$\triangle$ Для корреспонденции: Владимир Константинович Боженко ул. Профсоюзная, д. 86, г. Москва, 117997; vbojenko@mail.ru

Статья получена: 15.08.2018 Статья принята к печати: 28.11.2018

DOI: $10.24075 /$ vrgmu.2018.066

Just like chemotherapy and surgery, radiation therapy is an important cancer treatment modality. Among the problems that have been receiving a lot of attention lately are individual sensitivity of patients to radiation and the choice of adequate radiation strategy [1-3]. The efficacy of treatment can be improved by applying ultrahigh dose rate radiation, which at the same time can reduce the adverse effects of radiotherapy.
However, some authors report that increased dose rates produce no biological effects, whereas others point to severe biological damage caused by radiation with ultrahigh dose rates [4-7]. Our previous in vitro study [8] has demonstrated that exposure of peripheral blood lymphocytes to photon radiation with dose rates of $\sim 10^{9} \mathrm{~Gy} / \mathrm{s}$ entails some effects different from those of standard dose rates used in conventional radiation 
therapy. Our findings suggest that ultra high-dose photon radiation may be more beneficial for the patient in terms of its therapeutic ratio and the mechanisms of damage induced. Photon radiation delivered at ultrahigh dose rates may one day become a new component of cancer treatment.

The aim of this work was to study the effect of ultrahigh dose rate photon radiation generated by the experimental Mir-M machine on human cancer cell lines in vitro.

\section{METHODS}

Photon pulses were generated by the experimental high-current nanosecond electron accelerator Mir-M developed at the Joint Institute for High Temperatures, RAS (Moscow). The dose rates ranged from $1 \times 10^{9}$ to $4 \times 10^{9} \mathrm{~Gy} / \mathrm{min}$. Standard therapeutic doses of $1 \mathrm{~Gy} / \mathrm{min}$ used in patients with malignant tumors were generated by the therapeutic Co60-based gamma-ray unit Rokus-AM.

To study irradiation effects on a biological model in vitro, 2 cell lines were chosen: MelMtp-x (human melanoma cells from the collection of Blokhin Cancer Research Center, Russia) and A549 (human lung carcinoma 300114 from the Cell Lines Service repository). We assessed the cytotoxic effect of both radiation types by measuring the total number of killed cells, the proportion of apoptotic and necrotic cells, and the number of double-strand DNA breaks (DSBs).

The cells were thawed and cultured following standard protocols. A549 cells were cultured in the DMEM medium
(PanEco; Russia). MelMtp-x cells were cultured in RPMI 1640 (Gibco; USA). Both media were supplemented with 10\% fetal bovine serum (S1800; BioWest; France).

Irradiation of the samples on the "Mir-M" and therapeutic gamma-unit "Rokus-AM" were produced by the described methods [8].

The cytofluorometric analysis was performed on the Flow Cytometer Cytomics FC 500 (Beckman Coulter; USA) equipped with an argon ion laser $(\lambda=488 \mathrm{~nm})$.

The number of double-strand DNA breaks was estimated from the levels of phosphorylated H2A.X histone using the 17-344 H2A.X Phosphorylation Assay Kit for Flow Cytometry (Millipore; USA) according to the manufacturer's protocol.

Cell death pathways in the irradiated samples were studied 24 and 48 hours after irradiation with the help of the Annexin V-FITC Kit (Beckman Coulter; USA). The kit contains annexin V and propidium iodide $(\mathrm{PI})$ and can be used to simultaneously estimate the proportion of both apoptotic and necrotic cells [8]. The significance of differences was assessed by Sudent's t-test. Differences were considered significant at $p<0.1$.

\section{RESULTS}

The relative number of DSBs did not differ significantly between the A549 (human lung carcinoma) cells irradiated at standard therapeutic dose rates and those exposed to ultrahigh dose rate radiation (Fig. 1A). For MelMtp-x cells irradiated with standard therapeutic doses generated by Rokus-AM, the dose-effect
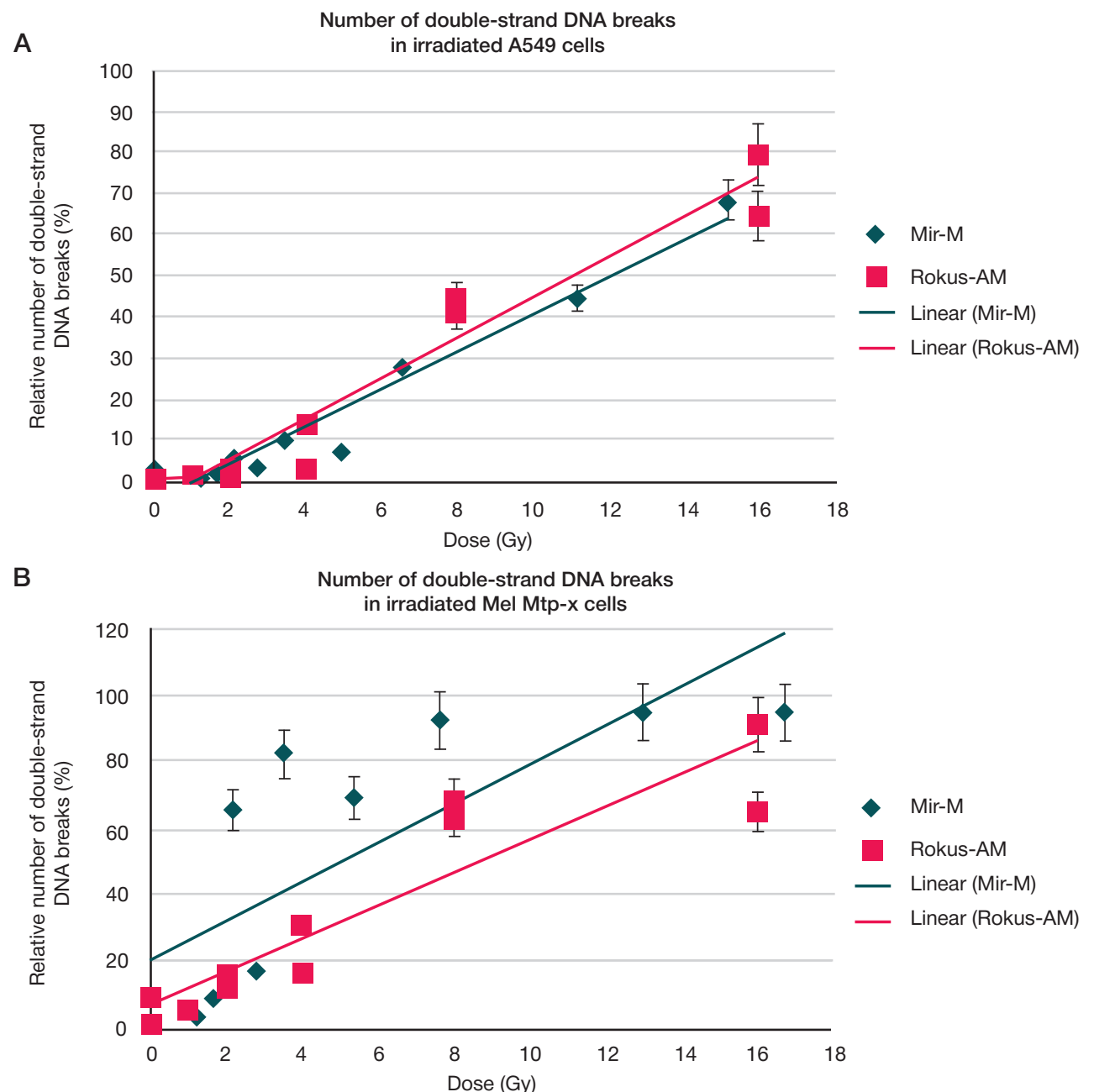

Fig. 1. Changes in the relative number of double-strand DNA breaks in A549 (A) and MelMtp-x (B) cells irradiated with therapeutic (Rokus-AM) and ultrahigh dose rate photon radiation (Mir-M) 
relationship was linear, in contrast to MelMtp-x cells exposed to Mir-M pulses that demonstrated a nonlinear relationship (Fig. 1B). Photon pulses applied to MelMtp-x cells at doses from 2 to 5 Gy caused a sharp increase in the relative number of DSBs $(65.7-80 \% ; p<0.1)$. For doses $>7$ Gy, the levels of DSBs did not differ significantly between the two studied radiation types, reaching their maximum of $95 \%$.

While analyzing the number of killed cells, we discovered a few different patterns possibly related to the radiation type applied and the specifics of the used cell lines (Fig. 2). The 24-h incubation of A549 cells irradiated with therapeutic gamma rays did not result in a significant increase in the number of killed cells; PI-positive cells made up only $6 \%$ of the total cells in the culture (Fig. 2A). But longer post-irradiation incubation time (48 h) caused a significant increase in the number of killed cells: $32.6 \%$ at 8 Gy and $41.2 \%$ at 16 Gy. Significant differences were also observed for the number of PI-positive cells between the MelMtp-x cultures irradiated at ultrahigh dose rates and subsequently incubated for $24 \mathrm{~h}$, unirradiated controls and MelMtp-x irradiated with therapeutic gamma rays generated by Rokus-AM (Fig. 2B). The proportion of killed cells grew significantly at a dose of 1.4 Gy and higher (14.8\%) reaching its maximum at 11.7 Gy (31.2\%). At the same time, extended 48-h incubation of the samples irradiated by the Mir-M machine did not cause a significate rise in the number of killed cells. Interestingly, the differences in the proportion of killed cells between the cultures undergoing 48-h incubation and irradiated by different radiation sources were insignificant.
In MelMtp-x cultures irradiated by Rokus-AM the proportion of killed cells was no bigger than 7\%; incubation time did not have any effect on cell mortality. Exposure to ultrahigh dose rates followed by 24-h incubation did not produce any significant therapeutic effect. But longer 48-h incubation led to a sharp rise in the proportion of killed cells in the sample: $13.4 \%$ at 2.5 Gy and $33.8 \%$. at $11.8 \mathrm{~Gy}$.

The analysis of cell death pathways revealed that the contribution of apoptosis to cell death was the largest (Fig. 3). For A549 cells, significant differences in the levels of apoptosis induced by photon radiation as compared to the therapeutic gamma rays generated by Rokus-AM were observed at doses $\geq 1.4$ Gy given that the cells were incubated for $24 \mathrm{~h}$ (Fig. 3A). When incubation time was increased to $48 \mathrm{~h}$, the differences were leveled out. However, the rise in the number of apoptotic A549 cells was significant for both irradiation types: in A549 cells exposed to ultrahigh photon radiation doses of 11.7 Gy the level of apoptosis was $21.4 \pm 3.2 \%$ after $24 \mathrm{~h}$ of incubation and $43.0 \pm 5.2 \%$ after $48 \mathrm{~h}$ of incubation. In the culture exposed to 16 Gy doses generated by Rokus -AM and incubated for $24 \mathrm{~h}$, the proportion of apoptotic cells was $4.8 \pm 0.7 \%$; 48 -h incubation resulted in the higher level of apoptosis (38.4 $\pm 4.6 \%$ ).

The proportion of apoptotic MelMtp-x cells measured after irradiation with standard therapeutic gamma ray doses did not exceed 4\%; incubation time did not affect cell mortality in the culture. Exposure to $\geq 5$ Gy photon radiation followed by 48-h incubation led to a reliable increase in the proportion of apoptotic cells (Fig. 3B).

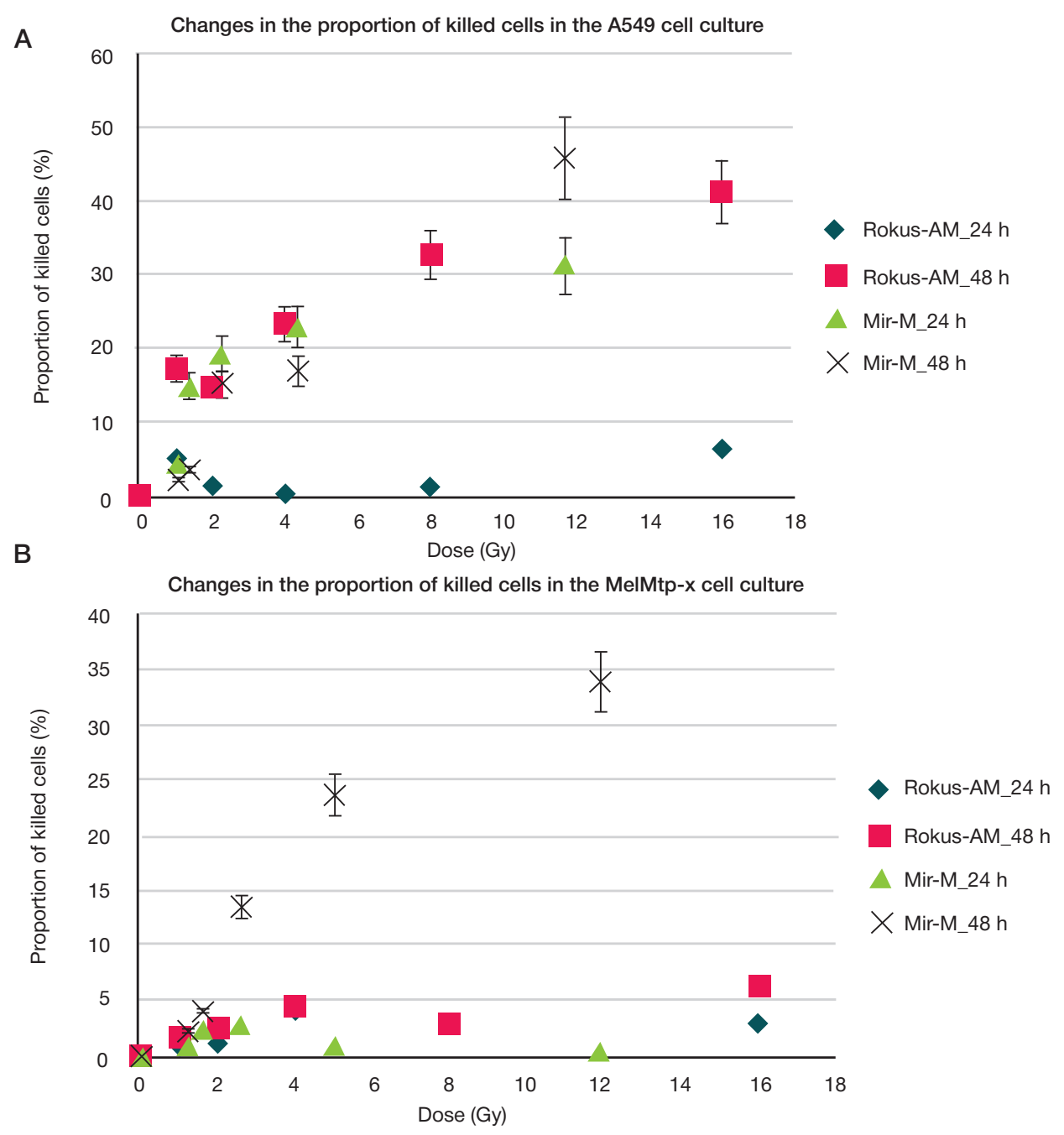

Fig. 2. Changes in the number of killed cells in A549 (A) and MelMtp-X (B) cell cultures irradiated with therapeutic (Rokus-AM) and ultrahigh dose rate photon radiation (Mir-M) 
The proportion of necrotic A549 cells measured after irradiation with photon pulses generated by Mir-M was significant at 4.3 Gy (38.6\% of the total killed cells in the culture) and at 11.7 Gy (30.6\%) if the cells were incubated for $24 \mathrm{~h}$ (Fig. 4A). This proportion shrank to $7.1 \%$ and $6.1 \%$, respectively, if the cells were incubated for $48 \mathrm{~h}$. This leads to a supposition that in the A549 culture necrotic cells are eliminated within 48 hours while apoptosis induced by ultrahigh photon radiation doses goes on.

While analyzing the level of necrotic cells in the irradiated MelMtp-x culture, we found out that it did not differ significantly between the cells exposed to different radiation sources and incubated for $24 \mathrm{~h}$ (Fig. 4B). When incubation time was extended to $48 \mathrm{~h}$, the proportion of necrotic cells increased in the samples irradiated by Mir-M with 1.58 Gy. At 2.6 Gy this proportion was $8.9 \pm 1.1 \%$ making up $66.4 \%$ of total cell death; at 11.8 Gy the level of necrosis reached $17.5 \pm 2.1 \%$ (51.8\% of total cell death).

\section{DISCUSSION}

Our study demonstrates that cell mortality measured in irradiated A549 (human lung carcinoma) and MelMtp-x (human melanoma) cells is higher for the cells exposed to photon radiation generated by Mir-M, although the number of induced DSBs is comparable between these two cell lines. The proportion of apoptotic cells is significantly higher in the A549 culture irradiated at ultrahigh dose rates.

The number of radiation-induced DSBs characterizes the DNA-damaging capacity of radiation and largely determines the fate of the affected cell [9]. The cell responds to this traumatic event by activating DNA repair pathways; if DNA integrity cannot be restored apoptosis is launched. Problems at any stage of DNA repair lead to chromosomal aberrations and eventually to cell death [10].

The number of DSBs estimated in our experiment is determined by the parameters of the radiation type and the state of DNA repair systems, in the first place. The relationships between the number of DSBs in A549 cells and the radiation type applied turned to be linear and almost identical, meaning that the damage caused by ultrahigh and standard therapeutic dose rates was comparable or that DNA repair mechanisms were intact in this cell line. In A549 cells irradiated at ultrahigh dose rates, apoptosis is induced $24 \mathrm{~h}$ after the exposure, whereas therapeutic gamma rays trigger it only $48 \mathrm{~h}$ after irradiation. One can assume that damage caused by the energies generated by RokusAM does not prevent A549 cells from activating their DNA repair mechanisms, while damage induced by Mir-M ultrahigh dose rates is soon identified by DNA repair mechanisms as

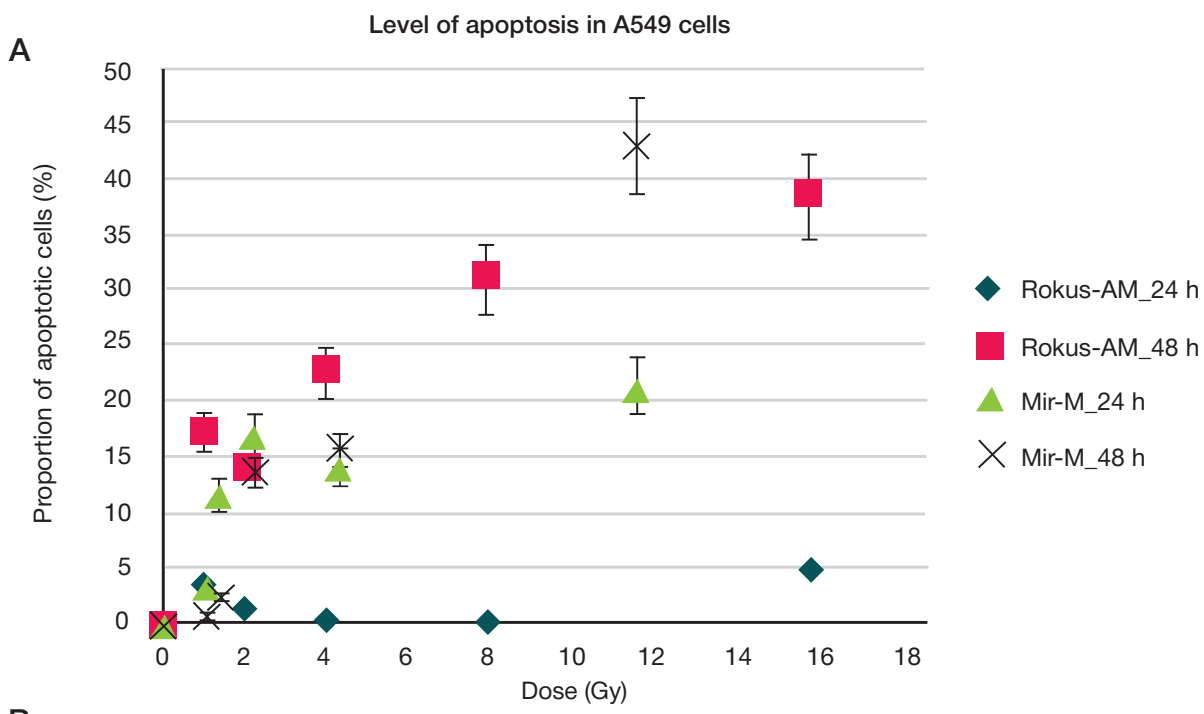

B

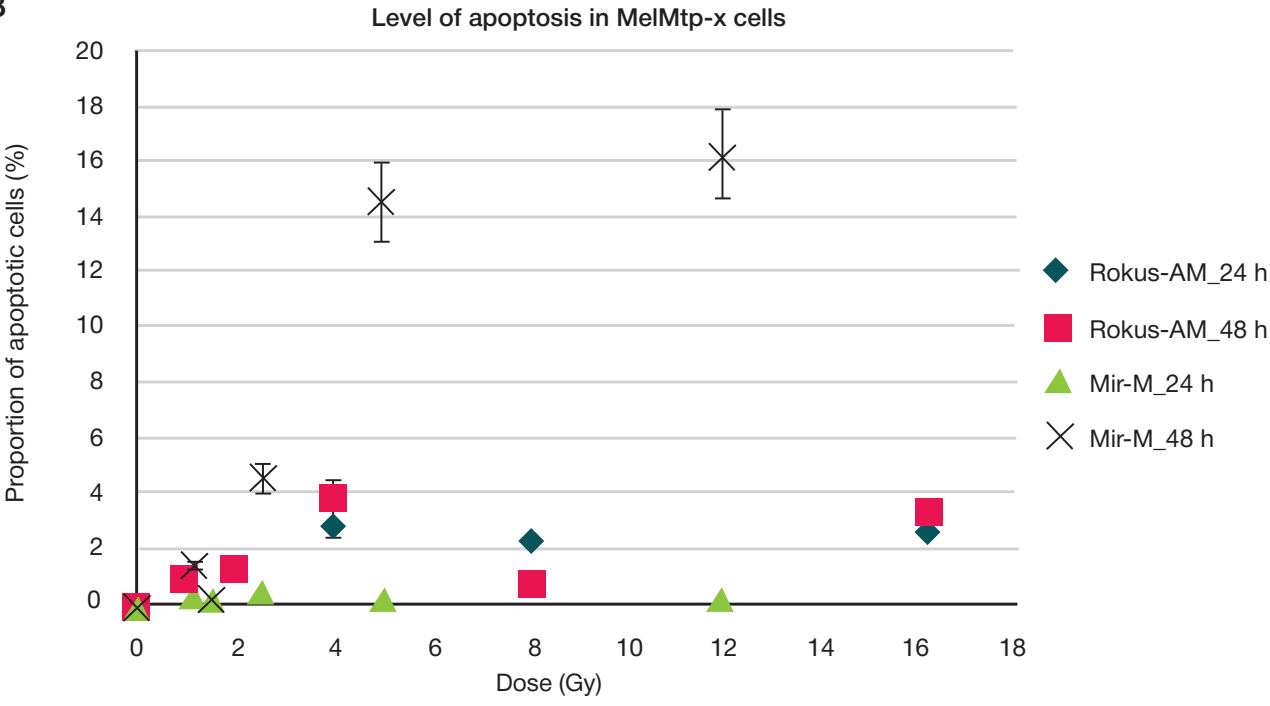

Fig. 3. Changes in the proportion of apoptotic cells in A549 (A) and MelMtp-x (B) cell cultures irradiated with therapeutic (Rokus-AM) and ultrahigh dose rate photon radiation (Mir-M). Staining: annexin V/ propidium iodide 

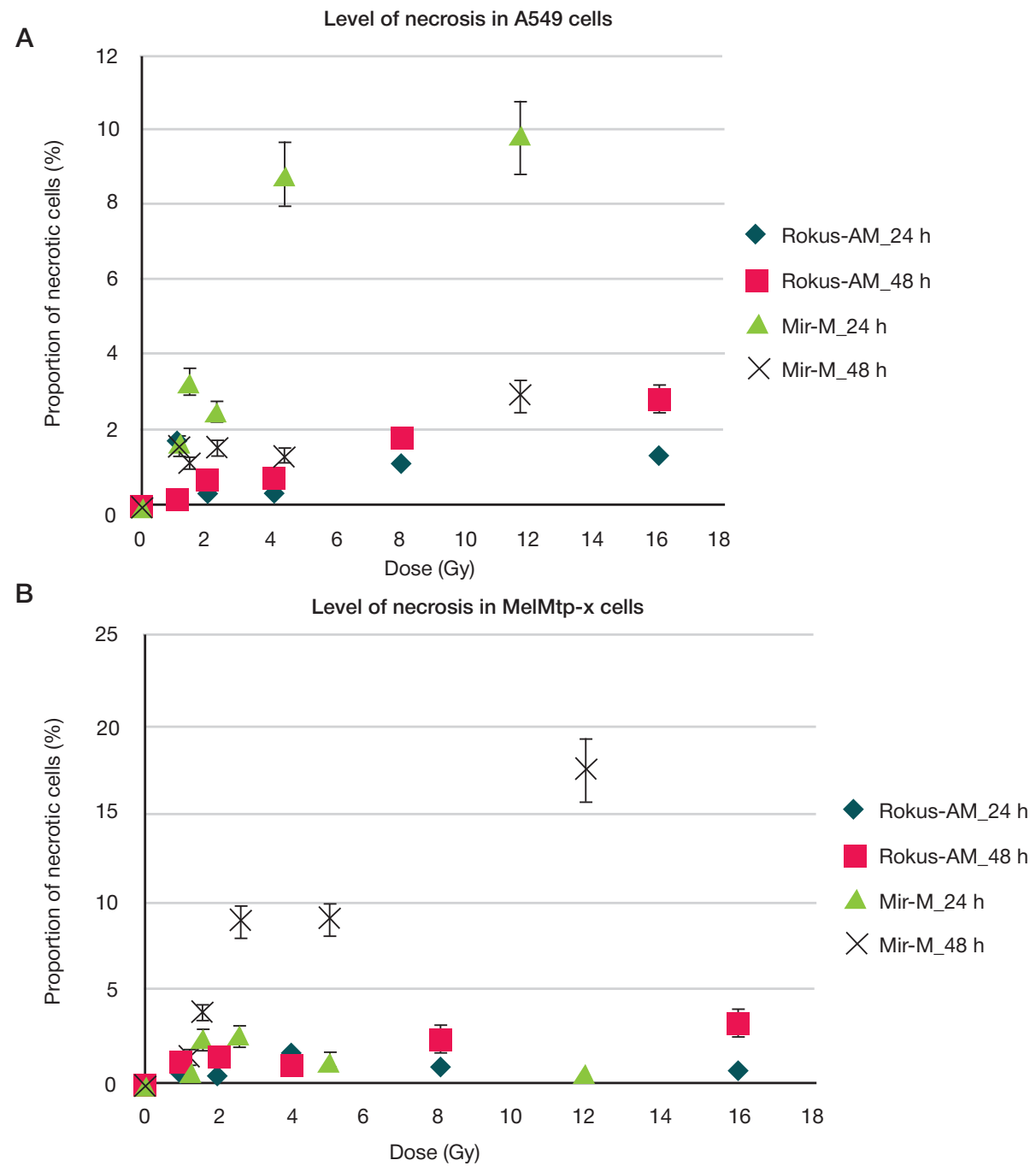

Fig. 4. Changes in the proportion of necrotic cells in A549 (A) and MelMtp-x (B) cell cultures irradiated with therapeutic (Rokus-AM) and ultrahigh dose rate photon radiation (Mir-M). Staining: annexin V/ propidium iodide

irreversible, and apoptosis is triggered as early as $24 \mathrm{~h}$ after the exposure. The proportion of apoptotic cells remains high $48 \mathrm{~h}$ after irradiation at ultrahigh dose rates but the level of necrosis drops.

The number of DSBs was significantly higher in the MelMtp-x culture irradiated with doses ranging from 2.15 to 7.6 Gy generated by the Mir-M machine. Possibly, at doses starting from $\sim 2$ Gy the type and extent of DNA damage in the cell prevent DNA repair systems from exerting their function. The results of cell death analysis in MelMtp-x cells are consistent with the reports of melanoma radioresistance $[11,12]$; exposure to radiation generated by the therapeutic gamma ray machine Rokus-AM hardly induces cell death, which means that either apoptosis is not activated in response to DSBs [13], or DSB reparation is effective [14]. Cell death was observed in melanoma cells irradiated at ultrahigh dose rates with the same doses ( $\geq 2.15$ Gy) that caused an increase in the number of DSBs. Cell death was induced on day 2 after irradiation. Both apoptosis and necrosis pathways were equally involved. Perhaps, exposure of melanoma cells to ultrahigh dose rates causes their irreversible damage, which in some cases both triggers apoptosis and activates other death pathways. To sum up, we have demonstrated that radiation generated by the experimental Mir-M machine kills significantly more cells than therapeutic gamma rays (Rokus-AM) in both studied cultures: A549 (human lung carcinoma) and MelMtp-X (human melanoma), although the number of induced DSBs is comparable between the cultures at the highest doses applied. In A549 cells irradiated by the Mir-M machine, apoptosis was more extensive.

The use of ultrahigh dose rate radiation holds promise for the treatment of radioresistant cancers and can minimize damage to the surrounding tissues when applied to solid tumors $[15,16]$.

Our findings may be interesting for clinicians looking for an alternative to conventional radiotherapy and for researchers studying the mechanisms of radioresistance and the ways to overcome it.

\section{CONCLUSIONS}

Our findings pave the way for further research of the effect of photon radiation delivered at ultrahigh dose rates on biological objects. This type of radiation may help to improve the efficacy of radiotherapy of radioresistant tumors and mitigate their detrimental effect on the surrounding healthy tissue. 
1. Habash M, Bohorquez LC, Kyriakou E, Kron T, Martin OA, Blyth BJ. Clinical and Functional Assays of Radiosensitivity and Radiation-Induced Second Cancer. Cancers (Basel). 2017; 9 (11): 147.

2. Orth M, Lauber K, Niyazi M., Friedl AA, Li M, Belka C, et al. Current concepts in clinical radiation oncology. Radiat Environ Biophys. 2014; 53 (1): 1-29. PubMed PMID: 24141602.

3. Ivanov SD, Stoljarova IV, Jamshanov VA, Minko BA, Belova WV, Vinokurov VL. Radiochuvstvitel'nost' DNK krovi kak predskazatel'nyj pokazatel' jeffektivnosti himioluchevoj terapii bol'nyh rakom shejki matki. Voprosy onkologii. 2016; 62 (4): 465-70.

4. Konopacka M, Rogoliński J. Can high dose rates used in cancer radiotherapy change therapeutic effectiveness? Contemp Oncol (Pozn). 2016; 20 (1): 449-52.

5. Slosarek K, Konopacka M, Rogolinski J, Sochanik A. Effect of dose-rate and irradiation geometry on the biological response of normal cells and cancer cells under radiotherapeutic conditions. Mutat Res Genet Toxicol Environ Mutagen. 2014; (773): 14-22.

6. Wang Z, Zhao Z, Lu J, Chen Z, Mao A, Teng G, et al. A comparison of the biological effect of $125 \mathrm{~J}$ seeds continuous low-dose-rate radiation and $60 \mathrm{Co}$ high-dose-rate gamma radiation on non-small cell lung cancer cells. PLoS One 2015; 10 (8): e0133728.

7. Brehwens K, Bajinskis A, Haghdoost S, Wójcik A. Micronucleus frequencies and clonogenic cell survival in TK6 cells exposed to changing dose rates under controlled temperature conditions. Int J Radiat Biol. 2014; (90): 241-7.

\section{Литература}

1. Habash M, Bohorquez LC, Kyriakou E, Kron T, Martin OA, Blyth BJ. Clinical and Functional Assays of Radiosensitivity and Radiation-Induced Second Cancer. Cancers (Basel). 2017; 9 (11): 147.

2. Orth M, Lauber K, Niyazi M., Friedl AA, Li M, Belka C, et al. Current concepts in clinical radiation oncology. Radiat Environ Biophys. 2014; 53 (1): 1-29. PubMed PMID: 24141602.

3. Иванов С. Д., Столярова И. В., Ямшанов В. А., Минько Б. А. Белова В. В., Винокуров В. Л. Радиочувствительность ДНК крови как предсказательный показатель эффективности химиолучевой терапии больных раком шейки матки. Вопросы онкологии. 2016; 62 (4): 465-70.

4. Konopacka M, Rogoliński J. Can high dose rates used in cancer radiotherapy change therapeutic effectiveness? Contemp Oncol (Pozn). 2016; 20 (1): 449-52.

5. Slosarek K, Konopacka M, Rogolinski J, Sochanik A. Effect of dose-rate and irradiation geometry on the biological response of normal cells and cancer cells under radiotherapeutic conditions. Mutat Res Genet Toxicol Environ Mutagen. 2014; (773): 14-22.

6. Wang Z, Zhao Z, Lu J, Chen Z, Mao A, Teng G, et al. A comparison of the biological effect of $125 \mathrm{~J}$ seeds continuous low-dose-rate radiation and $60 \mathrm{Co}$ high-dose-rate gamma radiation on non-small cell lung cancer cells. PLoS One 2015; 10 (8): e0133728.

7. Brehwens K, Bajinskis A, Haghdoost S, Wójcik A. Micronucleus frequencies and clonogenic cell survival in TK6 cells exposed to changing dose rates under controlled temperature conditions. Int J Radiat Biol. 2014; (90): 241-7.

8. Грабовский Е. В., Олейник Г. М., Крастелев Е. Г., Смирнов В. П., Хмелевский Е. В., Боженко В. К. и др. Анализ индукции
8. Grabovskij EV, Olejnik GM, Krastelev EG, Smirnov VP, Hmelevskij EV, Bozhenko VK i dr. Analiz indukcii apoptoza limfocitov perifericheskoj krovi cheloveka sverhintensivnym gamma-izlucheniem in vitro. Vestnik RGMU. 2017; (6): 59-66.

9. Jackson SP, Bartek J. The DNA-damage response in human biology and disease. Nature. 2009; 461 (7267): 1071-78. DOI: 10.1038/nature08467.

10. Belenko AA. Citogeneticheskie i fiziologicheskie jeffekty gammaizluchenija i impul'sno-periodicheskogo rentgenovskogo izluchenija v somaticheskih kletkah cheloveka [dissertacija]. Tomsk: 2016.

11. Zhukovec AG. Sovremennye principy i perspektivy lechenija melanomy kozhi. Onkologicheskij zhurnal. 2015; 9 (4): 69-76.

12. Matchuk ON, Zamulaeva IA, Kovalev OA, Saenko AS. Mehanizmy radiorezistentnosti kletok SP kul'tury myshinoj melanomy V16. Citologija. 2013; 55 (8): 553-9.

13. Tang L, Wei F, Wu Y, He Y, Shi L, Xiong F, et al. Role of metabolism in cancer cell radioresistance and radiosensitization methods. $J$ Exp Clin Cancer Res. 2018; (37): 87.

14. Dengina NV, Mitin T. Luchevaja terapija u bol'nyh s disseminirovannoj melanomoj: palliativ ili stremlenie $\mathrm{k}$ izlecheniju? Novosti onkologii. 2018 [19.02.2018]. Dostupno po ssylke: https://rosoncoweb.ru/news/oncology/2018/02/19-1/

15. Durante $M$, Bräuer-Krisch $E$, Hill $M$. Faster and safer? FLASH ultra-high dose rate in radiotherapy. Br J Radiol. 2018; (91):1082.

16. Durante M, Orecchia R, Loeffler JS. Charged-particle therapy in cancer: clinical uses and future perspectives. Nat Rev Clin Oncol. 2017 Aug; 14 (8): 483-95.

апоптоза лимфоцитов периферической крови человека сверхинтенсивным гамма-излучением in vitro. Вестник РГМУ. 2017; (6): 59-66.

9. Jackson SP, Bartek J. The DNA-damage response in human biology and disease. Nature. 2009; 461 (7267): 1071-78. DOl: 10.1038/nature08467.

10. Беленко А. А. Цитогенетические и физиологические эффекты гамма-излучения и импульсно-периодического рентгеновского излучения в соматических клетках человека [диссертация]. Томск, 2016.

11. Жуковец А. Г. Современные принципы и перспективы лечения меланомы кожи. Онкологический журнал. 2015; 9 (4): 69-76.

12. Матчук О. Н., Замулаева И. А., Ковалев О. А., Саенко А. С. Механизмы радиорезистентности клеток SP культуры мышиной меланомы В16. Цитология. 2013; 55 (8): 553-9.

13. Tang L, Wei F, Wu Y, He Y, Shi L, Xiong F, et al. Role of metabolism in cancer cell radioresistance and radiosensitization methods. J Exp Clin Cancer Res. 2018; (37): 87.

14. Деньгина Н. В., Митин Т. Лучевая терапия у больных с диссеминированной меланомой: паллиатив или стремление к излечению? Новости онкологии. 2018 [19.02.2018]. Доступно по ссылке: https://rosoncoweb.ru/news/oncology/2018/02/19-1/

15. Durante M, Bräuer-Krisch E, Hill M. Faster and safer? FLASH ultra-high dose rate in radiotherapy. Br J Radiol. 2018; (91):1082.

16. Durante M, Orecchia R, Loeffler JS. Charged-particle therapy in cancer: clinical uses and future perspectives. Nat Rev Clin Oncol. 2017 Aug; 14 (8): 483-95. 